\title{
Youth, Europe and the Nation: The Political Knowledge, Interests and Identities of the New Generation of European Youth
}

\author{
Daniel Faas
}

Europe is undergoing considerable demographic, economic, cultural and sociopolitical change. National citizenship identities have been challenged by the simultaneous processes of European integration and the migration of people into and across Europe. This paper explores how the current generation of youth relates towards Europe, and highlights the factors affecting their political knowledge, interests and identities. Although the article draws on mainly qualitative data from a study into the political identities of native youth and youth of Turkish descent in England and Germany, the results have implications for all European countries [1]. The research indicates that, in countries which promote European agendas and where schools and curricula emphasise an inclusive concept of Europe (e.g. Goethe Gymnasium in Stuttgart), young people have high levels of knowledge about Europe and make Europe part of their hybrid identities. However, in countries where governments and schools marginalise European agendas (e.g. Millroad School in London), young people struggle to relate positively to Europe, especially in workingclass contexts where national(istic) agendas come to the fore. The article raises important questions about the possibilities of promoting inclusive governmental and curriculum approaches and offers ways in which the knowledge and identity gaps between youth in different European countries could be addressed.

\section{Introduction}

The need for pan-European youth studies is increasing in importance as a result of social, demographic, economic, political and cultural changes in contemporary Europe. Many European Union (EU) countries have become culturally diverse 
societies and, at the same time, the increasingly supranational context in which political and educational systems are operating has challenged national agendas and identities. Notions of European identity and citizenship have been promoted by both the European Commission and the Council of Europe during the past two decades. Arguably, the most important inter-governmental agreement on the European dimension in education was the 1988 Resolution adopted by the Council of Ministers of Education, prompting educators to 'strengthen in young people a sense of European identity and make clear to them the value of European civilisation and of the foundations on which the European peoples intended to base their development today' (Council of Ministers of Education 1988, p. 5; emphasis added). Plans were made at the 1990 Rome summit to include European citizenship in the 1991 Maastricht Treaty, which theoretically provided the EU with the legal framework of its involvement in all the educational levels of the national educational systems of its member states [2]. The 1997 Amsterdam Treaty foresaw the encouragement of a more active and participatory citizenship in the life of the Union based on the complementarity of EU citizenship and national citizenship (Council of the European Union 1997). This is similar to what the EU proposed in its new Constitution, where Article I-10 states that 'every national of a Member State shall be a citizen of the Union. Citizenship of the Union shall be additional to national citizenship; it shall not replace it' (Council of the European Union 2004).

Despite these unifying calls for European identity and citizenship and a European dimension in education, all EU countries are presently autonomous in matters of education, which makes it difficult to develop a common approach to these policy initiatives. For example, Germany was a founding member of the European integration project and, as a result, schools and the curriculum throughout the 1980s and 1990s were used to construct a 'Europeanised national identity' (cf. Risse \& Engelmann-Martin 2002; Soysal et al . 2005). Building on various earlier initiatives to implement a European dimension in German schools (e.g. the 1978 'Europe in the Classroom' document), in 1990 the Standing Conference of the Ministers of Education (Kultusministerkonferenz (KMK)) published the revised policy document 'Europe in the Classroom' (Europa im Unterricht) in response to the 1988 Resolution of the Council of Ministers of Education. The 1990 document stated that the goal of education must be 'to awaken in young people the consciousness of a European identity ; to prepare them to be aware of their responsibilities as citizens of the European Community; and to promote mutual learning with young foreigners to foster the ability to feel mutual solidarity' (KMK 1990; emphasis added). In 1992, the KMK published a further review of progress and recommendations. The particular areas for development were identified as foreign languages as part of vocational qualifications; political and cultural education; school exchanges; school links; and teacher exchanges (KMK 1992). Several German federal states (such as BadenWürttemberg in 1994) subsequently overhauled their curricula to implement a European dimension. Since 1990, European Schools (i.e. schools that particularly emphasise a European dimension) have been set up across Germany. 
England, by contrast, has responded very differently to these calls for a European educational dimension. There was little reason why the country should reconceptualise her national identity in European terms and the processes of European integration have not seriously affected English policy-makers. The Europeanisation of British national identity was undercut by the special relationship with the United States; the geographical detachment from continental Europe; and England's postwar role in the Commonwealth. Europe did not appear among the cross-curricular themes and dimensions of the 1988 National Curriculum. The Department of Education and Science responded to the 1988 Resolution of the Council of Ministers of Education on the European dimension in education, stating that the government's policies were aimed at 'promoting a sense of European identity ; encouraging interest in and improving competence in other European languages; and helping students to acquire a view of Europe as a multicultural, multilingual community which includes the UK' (Department of Education and Science 1991; emphasis added). Unlike the Council of Ministers of Education, the Department of Education and Science's response employed a weaker language; for example, the key phrase 'strengthen in young people a sense of European identity' became 'promoting a sense of European identity'. However, advice and curriculum guidance on precisely what content and form the European dimension should assume has not matched official British concerns with other parts of the curriculum (e.g. multicultural education). Unlike in Germany, the curriculum is not in direct control of the government and there is room for English schools (and young people) to make their own sense of Europe.

The aim of this paper is to explore how young people relate to Europe; and to reveal the factors affecting their political knowledge, interests and identities. While the data I draw upon derive from a larger project designed to explore how German and English national agendas are reshaped by European and multicultural agendas at government level and what consequences these triple agendas have for the political identities of youth (Faas 2007), this article focuses on differently located groups of European youth in relation to the European agenda. I chose to compare Germany and England because these two European countries adopted rather different approaches to protect national identities. While England has marginalised European agendas and argued at length over what it means to be British, Germany has underplayed multicultural agendas and struggled to fit minority ethnic communities like the Turkish Muslims into its Europeanised concept of nationhood. Within these two countries, I decided to compare two types of secondary schools, one in a predominantly working-class environment and the other in a mainly middleclass area, to learn more about the role of social class for youth identities. I also chose to compare native youth and youth of Turkish origin, an ethnic group that arguably is not European. The Turkish Muslims are an under-researched and disadvantaged group (especially in England). None of the scant research on Turks in both Germany (e.g. Auernheimer 1990; Şen \& Goldberg 1994) and England (e.g. Küçükcan 1999; Enneli et al. 2005) has hitherto explored their responses to Europe, 
and the factors affecting their European political knowledge, interests and identities. The fact that the Turkish Muslims are the largest immigrant group in Germany (2.4 million people) but a relatively small and heterogeneous in England (200,000 people) has little significance in this context because most of the fieldwork was conducted at the institutional level in an inner-city borough of Stuttgart and London where the Turkish Muslims formed the largest minority ethnic community.

\section{Theorising and Researching Political Identities}

The research was informed by the insights offered by post-structuralist theory, particularly notions of a fragmented society in which identities (and concepts such as Europe) are seen as multidimensional, hybrid and fluid. The work of Caglar (1997), Mac an Ghaill (1999), Tizard and Phoenix (2002) and Dolby (2001) is particularly important for this study as it shows that the concept of identity is not a product, but a complex and multifaceted process of negotiation. Post-structuralist theorists, such as Foucault $(1980,1988)$ and Derrida $(1981)$, believe that there is no individual ' $I$ ' that interacts with the social context but that the only way an 'I' comes to exist is through the productive power of discourse. Secondly, post-structuralist approaches allow contradiction and multiple categories of identity and, most importantly, these multiple shifting identities do not have to be reconciled. Thirdly, a post-structuralist theoretical framework challenges the idea of a single monolithic truth and identity and regards all absolutes as constructions. Finally, poststructuralist approaches typically rely on predominantly qualitative methodologies, allowing young people to conceptualise their identities in their own words.

Drawing upon notions of multiple, fragmented and discursively produced subjectivities, Brah (1996, p. 124) argued that identity may be understood as 'that very process by which multiplicity, contradiction, and instability of subjectivity is signified as having coherence, continuity, stability; as having a core [...] that at any given moment is enunciated as the "l'". Brah's conceptualisation of identity leaves open the possibility for individuals to feel strongly about their identities, to construct subjects that can be 'spoken'. Hall (1996, p. 5) goes further to maintain that identity production also involves processes "which attempt to "interpellate", speak to us or hail us into place as the social subjects of particular discourses'. Hall (1996) has also suggested that, within a post-structuralist framework, identities can be understood as 'performed'. The notion of performativity (Butler 1997), particularly relating to students' negotiations of their political identities, was important for the design of this project because, from a deconstructionist position, performative suggests that ethnic and political identities are a continual establishment and articulation of binaries. The linking of techniques of the self (Foucault 1988) and performance opens up an exploration of the ways in which the social context mediates how subjects deal with the lived realities of specific institutional locations (Mac an Ghaill 1999).

The concept of identity/identities, meaning the communities young people felt they belong to, was also crucial for the conceptualisation of this study. In contrast, 
the notion of identification (Skeggs 1997) refers to the reasons and discourses students employed to identify with a particular community (e.g. Europe). It is also important to differentiate between hybrid (e.g. Hall 1992; Mercer 2000; Tizard \& Phoenix 2002) and hyphenated identities (e.g. Caglar 1997). Hybrid identities, according to Bhabha (1990), can be understood as 'mixed' identities that emerge as a result of the interconnections between diasporic or ethnic affiliations and political identities such as 'being European' [3]. In contrast, the notion of hyphenated identities, as understood by Caglar (1997), relates more to territorial or political identities, such as African American, rather than the emergence of a new identity. Hyphenation implies that an individual continuously mediates between two disparate cultures and territories. It is hard to know whether the young people in my research developed hybrid or hyphenated identities. However, the fact that many young people constructed their identities along ethnic and political dimensions, rather than mediating between two territories, suggests that the notion of hybrid identities is perhaps more accurate when analysing contemporary youth identities.

\section{Research Methodology and Design}

The design of the broader study combined quantitative and qualitative methods. At the macro-political level, which set the agendas for schools, I analysed and compared European Commission and national government documents on citizenship and Europe. At the institutional level, questionnaires were distributed in the opening stages of the project to about 100 students in each of the four secondary schools. The aim was to obtain broad insights into how students positioned themselves in relation to national and European citizenship identities. Then, I conducted six focus group interviews of four to five students in each school (single-sex and mixed native youth and youth of Turkish descent). The focus group method was chosen because it allowed me to explore the language different groups of students used to negotiate their political identities. This approach enabled me to follow up issues of the survey data analysis in more in-depth focus group interviews. The value of focus groups thus lied in the opportunity to listen to how students talked about Europe and the nation. Finally, I interviewed a total of 32 students (eight in each school). While the focus group method used group dynamics to elicit information, the individual student interviews built up personal profiles and thus allowed students to tell their personal stories regarding the research topic. Additional interviews with the Head, the Citizenship Education coordinator, the Head of Geography and the Head of Religious Education in each of the schools were conducted to gain insights into the role schools play in shaping students' positioning in relation to Europe and the nation-state.

In this article, I draw mainly upon the qualitative data obtained from focus groups and semi-structured interviews with young people. Although I had some a priori codes based on the interview schedules, I gradually adapted the thematic categories while reading through the transcripts. I looked at the ways in which students responded to questions and positioned themselves with particular discourses (e.g. 
European, national). When I tried to deconstruct the multiple meanings of these narratives I was guided by MacLure (2003), who argued that one of the most commonplace ways in which texts are stitched together is through the setting up of binary oppositions (e.g. 'us' and 'them'). 'One "side" comes to meaning through its difference with respect to a constructed "other" which is always lacking, lesser or derivative in some respect' (MacLure 2003, p. 10). The space opened up by language or discourse, she argues, is an ambivalent one; it is both productive and disabling. Without distance, we would not be able to imagine others as distinct from ourselves. However, my analyses can only provide an account of my reading(s). Other researchers might put together the truths in different ways.

The four schools matched in terms of the percentage of minority ethnic Turkish students, inner-city location (London and Stuttgart) and social intake. They had some similarities and differences in relating to Europe, as summarised in Table 1.

The young people therefore will have experienced quite contradictory and different messages about Europe. More specifically, Tannberg Hauptschule mediated national agendas through a dominantly European and, arguably, at times a Eurocentric approach (e.g. the Head of Religious Education argued that if a religious symbol was allowed in class then it should be the cross and not the headscarf; we are still Christian Occidental [white and European]'). The Tannberg curriculum emphasized European agendas in subjects such as Geography and History. For example, in Geography, the entire Year 7 (ages 12-13) was spent looking at Europe and students were given a geo-political overview of Europe before they studied either France or Great Britain, the physical and human geography of northern Europe, Mediterranean countries as well as the changing landscape of Europe. Goethe Gymnasium, while allowing young people to keep their cultural and ethnic identities, emphasised Europe as a common bond and thus interpreted the concept of Europe differently from Tannberg Hauptschule (which I would call 'multicultural Europeanness'). The school prospectus stated that 'the ethos of our school is characterised by mutual respect and tolerance towards other people. Our students learn the manifoldness of European languages, cultures and mentalities and can thus develop their own identities within our school. [. . .] Europe as a cultural area is one of our guiding principles'.

In contrast, as a result of England's rather lukewarm approach to Europe, European issues were a relatively low priority in the two London schools (cf. Table 1). Millroad School, which reasserted the concept of cultural pluralism, offered only limited acknowledgement of the processes of Europeanisation. The school prospectus reveals that the school 'recognises that the social, cultural and linguistic diversity in our community is an important resource and an aspect of our ethos we seek to promote and celebrate. [. . .] We give our young people the knowledge and personal strength to be good citizens in a multicultural world'. The present Geography curriculum, for instance, only has one European teaching unit in Year 8 (Italy: a European country) while highlighting the importance of an international perspective with units on Japan and Brazil in addition to local and national issues. 
Table 1 Summary of the profiles of the German and English secondary schools.

\begin{tabular}{|c|c|c|c|c|}
\hline & \multicolumn{2}{|c|}{ Germany } & \multicolumn{2}{|c|}{ England } \\
\hline & $\begin{array}{l}\text { Tannberg } \\
\text { Hauptschule }\end{array}$ & $\begin{array}{c}\text { Goethe } \\
\text { Gymnasium }\end{array}$ & $\begin{array}{l}\text { Millroad } \\
\text { School }\end{array}$ & $\begin{array}{l}\text { Darwin } \\
\text { School }\end{array}$ \\
\hline $\begin{array}{l}\text { School } \\
\text { population }\end{array}$ & $\begin{array}{l}320 \text { students, } \\
18 \% \text { Turkish }\end{array}$ & $\begin{array}{l}564 \text { students, } \\
5 \% \text { Turkish }\end{array}$ & $\begin{array}{l}1204 \text { students, } \\
26 \% \text { Turkish }\end{array}$ & $\begin{array}{l}1507 \text { students, } \\
2 \% \text { Turkish }\end{array}$ \\
\hline Location & $\begin{array}{l}\text { Working-class } \\
\text { inner-city }\end{array}$ & $\begin{array}{l}\text { Middle-class } \\
\text { inner-city }\end{array}$ & $\begin{array}{l}\text { Working-class } \\
\text { inner-city }\end{array}$ & $\begin{array}{l}\text { Middle-class } \\
\text { inner-city }\end{array}$ \\
\hline $\begin{array}{l}\text { European issues } \\
\text { (a) Languages } \\
\text { (b) Geography } \\
\text { and History }\end{array}$ & $\begin{array}{l}\text { English only } \\
\text { Entire Year } 7 \\
\text { Geography, half } \\
\text { of Year } 6 \text { History }\end{array}$ & $\begin{array}{l}\text { English, French } \\
\text { Entire Year } 6 \\
\text { Geography, half } \\
\text { of Year } 7 \text { History }\end{array}$ & $\begin{array}{l}\text { French, Spanish } \\
\text { One unit in Year } \\
8 \text { Geography } \\
\text { and History }\end{array}$ & $\begin{array}{l}\text { French, German } \\
\text { One unit in } \\
\text { Years } 7 \text { and } 8 \\
\text { Geography and } \\
\text { History }\end{array}$ \\
\hline
\end{tabular}

Darwin School emphasised Britain as a common bond (identity) but, like Millroad, made little efforts to integrate students on the basis of European membership. 'The school strives to be a high-performing inclusive community school, fully committed to active citizenship and academic excellence. We value all who learn and work here; promoting a strong sense of community within and beyond the school' (school prospectus). Since neither of the two London schools had high levels of promotion of Europe, young people struggled to a greater (Millroad) or lesser (Darwin) extent to relate positively to Europe, and they were also less knowledgeable about the EU.

\section{Geo-political Knowledge and Interests}

The different prioritisation of European agendas at government level and in school curricula is an important factor affecting the political knowledge of, and interest in, Europe and the EU among the new generation of youth. For example, young people in the two German schools had significantly higher scores when asked to locate 10 European countries correctly on a geo-political map of Europe than their counterparts in the two English schools.

Table 2 shows that over 80 per cent of students in the German sample correctly identified the location of six western-central European countries. In contrast, only one country (Britain) was correctly identified by eight out of 10 students in the English sample. Eastern European countries (Poland and Ukraine) and Turkey were the least correctly located countries. On average, 62.6 per cent at Tannberg versus 77.3 per cent at Goethe compared favourably to 34.4 per cent and 48.9 per cent from Millroad and Darwin School, respectively. Students in the middle-classdominated schools (Goethe and Darwin) were also significantly better at locating European countries on a map than students in the working-class-dominated schools (Tannberg and Millroad). 
Table 2 Students' correct location of countries on a map of Europe.

\begin{tabular}{lcccccc}
\hline & $\begin{array}{c}\text { Germany } \\
\text { (per cent) }\end{array}$ & $\begin{array}{c}\text { England } \\
\text { (per cent) }\end{array}$ & $\begin{array}{c}\text { Tannberg } \\
\text { (per cent) }\end{array}$ & $\begin{array}{c}\text { Goethe } \\
\text { (per cent) }\end{array}$ & $\begin{array}{c}\text { Millroad } \\
\text { (per cent) }\end{array}$ & $\begin{array}{c}\text { Darwin } \\
\text { (per cent) }\end{array}$ \\
\hline Britain & 85.6 & 85.1 & 76.8 & $93.5^{* *}$ & 81.3 & 89.1 \\
Germany & 89.6 & $51.0^{* *}$ & 85.3 & 93.5 & 37.4 & $65.3^{* *}$ \\
Spain & 86.1 & $52.4^{* *}$ & 78.9 & $92.5^{*}$ & 38.3 & $67.3^{* *}$ \\
Finland & 25.7 & $8.7^{* *}$ & 15.8 & $34.6^{* *}$ & 4.7 & $12.9^{*}$ \\
Italy & 94.1 & $64.4^{* *}$ & 89.5 & $98.1^{*}$ & 54.2 & $75.2^{* *}$ \\
Turkey & 66.8 & $33.2^{* *}$ & 58.9 & 73.8 & 33.6 & 32.7 \\
Portugal & 81.2 & $37.5^{* *}$ & 74.7 & 86.9 & 28.0 & $47.5^{* *}$ \\
Poland & 58.9 & $14.4^{* *}$ & 48.4 & $68.2^{*}$ & 11.2 & $17.8^{*}$ \\
France & 85.6 & $56.7^{* *}$ & 75.8 & $94.4^{* *}$ & 43.0 & $71.3^{* *}$ \\
Ukraine & 30.2 & $10.6^{* *}$ & 22.1 & $37.4^{*}$ & 12.1 & $8.9^{*}$ \\
Average & 73.3 & $41.4^{* *}$ & 62.6 & 77.3 & 34.4 & 48.9 \\
\hline
\end{tabular}

*Significance below $0.05, * *$ significance below 0.01 .

Young people in the two German schools in Stuttgart, particularly at Goethe Gymnasium, also had a wider range of opinions when talking about Europe. For example, Leo (a German boy at Goethe) argued that 'I think about the expansion, and I also cast my mind back to Columbus. Europe used to be the centre of the world; many things started here', thus alluding to the industrial revolution in eighteenth century England as well as the 'discovery' of America by Christopher Columbus in 1492. Semra (a Turkish girl) alluded to the European Union's official motto 'United in Diversity', and the girls also referred to the decade-long debate among policymakers and politicians about the future structure of Europe:

D.F.: What comes to your mind when you hear the word 'Europe'?

Semra: Well, Europe consists of countries that have got together, a community with the same currency. But you can't say that that's a giant country cos there are different languages and you can't say that Europe is one culture. The people are kind of similar but there are nevertheless other cultures and France isn't like Germany and it's different in England. Europe just has the same currency but not the same language and culture.

Nilgün: For me, Europe is more geographical. It's also more simple that you can move from one country to another. There's the Euro, but I don't really like it. I mean, people think that all Europeans are the same but, in reality, there are quite different cultures. I've got relatives in France and when we crossed the border it looked quite different. It's not one country.

Sevilin: You can't change the cultures, only the laws. I don't think there'll ever be something like a United States of Europe. That's somehow not possible. Maybe it's just a term cos in America each state has its own laws too but the language and culture is the same, and that's not the case in Europe.

Zeynep: They all see themselves as Americans.

Unlike students at Goethe Gymnasium who were able to engage in discussions about Europe, Tannberg students only listed some concepts (e.g. the Euro) when 
they heard the word Europe and preferred to talk about local and national political issues instead. The predominantly working-class background of young people at Tannberg Hauptschule may have been a reason for this. For example, the group of four native German boys I interviewed were happy to talk about notions of tax reform, unemployment, apprenticeship places, and also mentioned the job competition they face with 'foreigners', as the following quotation demonstrates:

D.F.: What do you see as important political issues nowadays? What interests you? Jan: Well, the war and stuff. There was a war in Iraq. If an Iraqi lives here, then there'll be prejudices again although he can't do anything that he's Iraqi.

Michael: I haven't watched the news for half a year.

Florian: I don't know what's going on in politics. I mean, the things that I need to know, apprenticeship places and stuff like that, I know. But other things don't bother me. And even if it interested me I couldn't do much about it anyway. So, I just can't be bothered.

Dominik: Well, I haven't watched any news either for the past week. I'm only interested in unemployment, that the foreigners get a job and take our jobs away. They work for less money, on the black market and stuff, and take the chances away from others.

These young people did not perceive European and global political topics to be particularly relevant to their lives (except for Iraq war). And although both German and Turkish youth to whom I spoke engaged in a discussion about the possibilities of a Turkish EU membership, their general knowledge about Europe and the EU seemed to be rather limited. The Turkish students at Tannberg listed some concepts including 'the Euro', 'the EU', 'western world' and 'advanced rich countries', but were unable to engage in a wider discussion about Europe and the EU. Tamer, for example, alluded to the 'united in diversity' motto of the EU (cf. Council of the European Union 2004) and Ugur referred to the EU's peace-keeping role:

D.F.: What do you know about Europe, about the European Union?

Tamer: It's a community.

Yeliz: That's what I think too.

Umay: I don't know. I'm not so sure.

Tamer: It's a community of different countries.

Cari: EU, countries that belong together; they talk about politics of different countries; they have negotiations and debate what they can do. It's a strong, political team.

Yeliz: If a country needs help then the other EU countries will help. They have treaties with each other.

Ugur: The European Union is a good thing; we don't have war today.

Native German students in the study also revealed some factual knowledge about Europe and the EU. For example, the group of boys and girls referred to notions of power as well as transatlantic and inner-European relationships. Not only was Sebastian aware of the strength of the common currency, but he and Tobias also 
alluded to the political and economic benefits of a united Europe. Drawing upon the dispute over the Iraq War in 2003, Jessica reminded the boys that Europe still does not speak with one voice:

D.F.: What do you know about Europe and the EU?

Franziska: The Euro.

Tobias: I think it's better now when it's Europe than when the countries were alone. We are too weak. We would have no chance, for example, against America. The Euro strengthens everything, of course. And the English always say 'travel to Europe'; they still think they are on their own. That's a bit silly what they think, I just find that the wrong attitude.

Sebastian: Well, I think the deutschmark used to be weaker than the dollar. Now the dollar's become weaker than the Euro. And when you're together, when you're a community, you're a lot stronger than on your own.

Jessica: Lots of languages, lots of cultures, well, I think that Europe is really a comprehensive image although the countries don't always stick together. You could see that with the Iraq war and America, some countries supported America. Germany didn't. And that's where you can see that the countries don't really always stick together.

In contrast, native and Turkish students' knowledge of, and interest in, European issues was much more limited in the two English schools, particularly at Millroad School where the young people I interviewed struggled to talk about Europe in political terms. For example, the group of British girls did not appear to know much about the expansion of the EU on 1 May 2004 despite the fact that this discussion took place days before this event. Their discourse very much focused on the disagreement between France and England regarding the Iraq War:

D.F.: What do you know about Europe, about the European Union?

Ellie: [laughing] Nothing!

Katie: Nothing.

D.F.: What is happening at the moment in Europe?

Ellie: Erm, there's a lot of disagreement about the Iraq war, whether it should have happened and stuff. Because, um, England was very go for it, and I know France was very very against it and I think that's I dunno which other countries, but I think there were quite a lot more that were saying we shouldn't do it, and the English government, even though most of the people in England didn't want it to happen, decided to go ahead with it anyway.

D.F.: In the UK, they are now talking about this European Constitution; they want a referendum for that. Have you heard of that recently?

Katie: Like, I read a lot of newspapers and I watch some news, but I've never heard of that. Well, they may not, you know, advertise it as much as they should do. None of us here heard that; so that must mean that they're not doing as much as they can to make people know that it's expanding.

The girls were not aware of the current debate about a European Constitution, and Katie pointed towards what she perceived as a low media representation of 
European issues in England. Other British students I interviewed, such as Robert, claimed that the political and educational marginalisation of European agendas in England led to his poor knowledge about Europe and its institutions. 'The European parliament is never like televised, we don't know what they actually, if Parliament [Westminster] passes a bill we'll know about it, I don't know what goes on in the European parliament'. Similarly, Turkish respondents had difficulties to make sense of how Europe and the EU work in political terms:

D.F.: What do you know about the European Union or Europe?

Baris: European Union, what's that?

Sarila: Well, nobody knows nothing about it basically.

Baris: What's the European Union?

Sarila: You think I know?

Baris: I heard about it, but I don't know what it is.

Sarila: Me neither.

Halil: Is it the power?

Baris: I'm asking you.

Sarila: I don't really know, no.

Halil: Cos the Union-

Baris: The Union's a bunch of people that decides something, but I don't know.

Halil: It's the only power.

Other students in the sample, such as Olcay, referred to the Turkish EU membership bid when asked what they know about Europe in political terms. Europe was seen through a Turkish national (i.e. familiar) lens. Those who argued against membership typically said that Turkey's laws and morals do not meet European standards and that the country is very poor with a great deal of people being homeless. Similarly, in their discussions about Europe and the EU, many young people I interviewed at Darwin School struggled to talk about the EU, as can be seen in the following quotation from the discussion with a group of five British girls:

D.F.: What sorts of things do you know about Europe and the European Union?

Anne: Not much!

Victoria: It's really difficult,-

Anne: I don't know anything.

Victoria: -totally out of my depth.

Elizabeth: It's quite confusing cos it changes so much, that people-

Anne: The Euro.

Sophie: There's places part of it [indistinct]

Elizabeth: Oh, isn't there a referendum or coming up for something or other?

Victoria: A what? What's that?

Elizabeth: I dunno. I just heard it, walking through my house and the news was on somewhere, this whole thing about-

Victoria: What's a referendum?

Elizabeth: I don't know.

Anne: I know about the euro because I was in Ireland when it was going through.

Victoria: They don't have it in Ireland. 
Arguably, the limited coverage of European issues in the British mass media and the failure of schools to promote a European dimension alongside multicultural education in the National Curriculum (cf. Tulasiewicz 1993; Convey \& Merritt 2000) were all responsible for this low level of knowledge of, and interest in, European issues. Similar reasons can be deployed to justify the difficulties the sample of Turkish students had to engage in European political discourses. Some Darwin students referred to 'power', 'opposition to America' and 'community of countries'. Typically, however, Turkish interviewees neither knew the purpose of the EU nor how European institutions work. This can be seen in the following quotation from the discussion with a group of male and female students:

D.F.: What do you know about the European Union or Europe actually?

Adem: It happened after World War Two; France and Germany, they like made an agreement, and then loads of other countries joined or something.

Neylan: What happens when you're in the EU anyway?

Afet: Nothing, you're just

Adem: No, you get to, the United Nations.

Neylan: What do you get?

Adem: You get into the United Nations.

Neylan: So what, who cares? Why can't the whole world be in it? That's not fair.

Adem: Cos they're not.

Neylan: It's just stupid!

Although political knowledge and interest is not necessarily the basis of political identities, the evidence in my research suggests that it nevertheless affected the identity formation processes of the current generation of European youth.

\section{Youth and European Political Identities}

As a result of Goethe Gymnasium's liberal approach of emphasising Europe as a common bond and the European curricular dimension, both native youth and youth of Turkish descent engaged in a discussion and felt positive about Europe although there is still room for students to enhance their European political knowledge. Most Goethe students made European identification dependent on stays abroad (e.g. 'I only know Germany; if I was living in Spain for a few years, then I'd more say that I'm European cos I'd be familiar with different countries'), parental influence (e.g. 'my parents experienced a lot and tell me a lot about other countries and cultures), and the school curriculum (e.g. 'we learn a lot of European languages in school and talking in Italian or French to other people makes me feel partly European'). The following excerpts indicate that the youths I talked to felt positive about Europe:

D.F.: To what extent do you see yourself as European?

Ali: Erm, of course I'm European. Europe is very big and is getting bigger and bigger. And when Turkey joins the EU it'll be even bigger. Europe is getting more and more important to me cos of Turkey. [.. .] 
Samuel: Europe, the EU, plays an important role in my life. When I go abroad it's just so simple. There are hardly any border controls and it's just getting easier and easier. The countries are not on their own anymore and are together; and there are no borders anymore, very open. [...]

Mariam: I feel European because of the Euro. The Euro impacts on your life. I mean, in the newspaper they always talk about the Euro, Eurozone, Europe and so and I've noticed that the countries are getting closer and closer and not every country has its own policy. And the economy has grown together too. And you can travel to other countries without any problems at the borders.

Ali linked European identification with Turkey's role in Europe whereas the two German students focused on European elements in their lives, including the Euro and free movement within several European countries. The above statements were suggestive of the fact that the European integration process, be it the expansion to include countries like Turkey (e.g. Ali) or deeper political and economic cooperation (e.g. Mariam), also seemed to contribute to students' identification with Europe.

Paradoxically, despite having some knowledge about Europe as we saw earlier, neither the native German nor the Turkish students at Tannberg Hauptschule saw themselves as 'European'. Perhaps the at times Eurocentric approach made it difficult for young people to relate positively to Europe as a political identity. Europe, for these Turkish youth, was not separate from the concept of being German - 'being German', in other words, equals 'being European'. Hence, most of the Turkish students I interviewed argued that they felt European only 'because I live here in Germany [. . .] we are Germans and Germany is part of the EU'. In contrast, each of the four Turkish boys in one focus group claimed that 'I don't think I feel part of Europe [. . .] I feel more Turkish'. These findings suggest that Turkish students who privileged their Turkishness over German national identity had no connection to Europe, whereas those who prioritised the German part of their hybrid political identities were able to feel European. Some (German) Tannberg youth employed the image of a chain of identities arguing that Stuttgart, Germany and Europe were all interlinked and thus sites for identity formation:

D.F.: Where do you feel you belong to?

Dominik: Stuttgart, or Germany.

Jan: Stuttgart, Germany and Europe.

D.F.: Why?

Dominik: Don't know.

Jan: Stuttgart belongs to Germany and Germany is part of Europe.

Michael: Well, I mean, I was born in Stuttgart, grew up in Germany and Germany belongs to Europe.

Florian: I live here and when somebody lives in a country, then he's a citizen of that country and that's why we also belong to Europe, Stuttgart and Germany.

Jan: If someone asks me, then I say, I am now living in Stuttgart but I was born in Berlin. I've hardly said European really. Maybe that's just a habit that you don't really say that yet, but when you are more used to it [Europe], then you would say that. 
In contrast, in England, where successive governments have reinforced national agendas and identities through citizenship education and developed multicultural school policies while marginalising the European dimension (despite the 1991 policy statement to promote a sense of European identity, cited earlier), young people struggled to relate positively to Europe as a political identity. For example, at Millroad School in London, the group of Turkish boys construed the notion of Europe in monocultural terms:

Yildiran: Let's say I go to India or something, or I don't know, I'm just giving Egypt or America or any other Canada, Canada or something then I would say 'ah, I'm coming from Europe', basically that's about 'I'm coming from Europe' but I'm not like, you know European or anything.

Muhammad: I wouldn't even say Europe, you can't say I'm European.

D.F.: Why not?

Muhammad: Unless your races country is a European country as well ... like where your from, whether your first country is in Europe cos basically we're used to seeing white people, white people as European, so basically-

Yildiran: English people.

Muhammad: I would say I live in Europe but I'm not European.

Onan: Yeah same, because you're not living all around Europe, you're just living in one country.

Khan: Erm, the thing is that if you was Europe, yeah, you'd like understand that, you know, I come from Europe, cos you know yeah, but I can't say I'm European cos l'm not Christian.

Muhammad: I don't say I'm Christian, I say I believe in Christianity but I don't say I'm Christian, that's the same as saying I'm from Europe but I'm not European.

The notion of 'being European' did not sit comfortably with any of the Turkish boys in this group; most notably Muhammad, for whom identification is based upon the concept of 'race' rather than residence. Like the Turkish students, the British students I spoke to positioned themselves outside the notion of Europe by drawing upon a modified version of the theme of us (English or British) and them (continental Europeans), as shown in the following excerpt:

Joey: Don't really see ourselves as part of Europe. It's more like all the countries that are joined together and we're just sort of the odd one out that drives on the left and has the pound.

Eddie: Yeah, because we're sort of separated, we're an island off Europe. We're not, yet, because I don't see myself as part of Europe really. We're off Europe.

Kelly: Yeah, it's like they always say British and then they say European. Like, when you say European, for me I think of places like, erm, erm, countries like ... like I can't think of, like-

Eddie: Switzerland and France. And like places further down.

Joey: Probably Germany actually.

Kelly: Yeah. And it's like, cos its right [indistinct] island, but in a way, and we are different in similar in ways, like you know. 
Joey: Especially now because we're sort of less tied to Europe and more tied to America, we're sort of very westernised.

Similarly, at Darwin School, Europe played a less important role in the lives of young people compared with local and national identities. Despite being interested in the EU and aware of England's position within Europe, including the referenda on the single currency and the proposed Constitution, Mustafa (a Turkish boy) did not see himself as European:

D.F.: To what extent would you see yourself as European?

Mustafa: I don't really see myself as European, because, erm, I don't know, I just, erm, I'm not sure because I'd sort of be like failing my argument now if I said that I don't see myself as European because if I was born in Europe I'd see myself as European, but I'm not born there so I guess I call myself British, cos I was born here and, like growing up here, since day 1 . That's it.

D.F.: That's interesting that you are saying that, because you were born in England, and England has been part of the EU for decades, and now you were just saying 'I'm not born in Europe'?

Mustafa: But the thing is, I don't see as England being a strong . . . I know they're quite strong in Europe, but I guess like I think like Europe's sort of latching onto England, and I think England's more distant from Europe, even though they're quite strong contenders in the European Union. Now if you've seen the news, they're actually thinking to vote not to be key contenders in the European Union, so they'll be more of the people that's on the marginal lines of Europe, instead of the core players of the, like Germany or France.

Native British students at Darwin also referred to the country's separateness and struggled to position themselves within a European discourse. In the following discussion, the British students who took part in the mixed-sex focus group agreed that Europe is a rather irrelevant, distant community with which they have nothing much to do. The discussion thus shows how Europe is defined as a geographical zone and too broad a category to identify with:

D.F.: What role would you say Europe plays in your life?

Adam: Nothing.

Charles: Nothing, whatsoever.

Clara \& Olivia: [murmur agreement]

Adam: Wouldn't really like it to play much of a role either.

Charles: It's got nothing to do with me, it's a bit irrelevant.

Charlotte: You wouldn't say you were French cos that's in Europe.

Adam: It's just a zone.

Charles: You wouldn't say 'hello, I'm European'.

D.F.: Why wouldn't you say that?

Adam: Cos you're an individual from many different places, in Europe.

Charles: European is too broad a generalisation to class anyone as, whereas British 
obviously is much smaller, has less minorities, less groups to put yourself in, so it's easier to say 'Yes I am British', but even in England, even in London, few people would say 'yes I'm British', they'd say 'I'm from London', 'I'm from Essex', 'I'm from Kent', or, 'I'm from Oaks', cos people like to give themselves the smallest community to put themselves within, so they can feel more special.

The tension between Englishness (or Britishness) and Europeanness is played out in the above passage. The girls felt that by saying you are from England it is 'kind of more personal, a more detailed answer of where you actually come from' whereas saying you are European could mean many different things.

The above discussions indicated that social class positioning also affected young people's political identities (although it was not possible within the limits of this research to determine the relative importance of this factor). Privileged backgrounds worked differently in each country. German and Turkish students at Goethe Gymnasium in Stuttgart, which promoted European alongside multicultural values, had the best opportunities of relating to Europe as a political identity (national-European identities). Their privileged backgrounds allowed them to take part in school exchanges and to travel across Europe, and thus benefit from the opportunities associated with Europe. Youth at Darwin School in London also benefited from their socio-economically advantaged backgrounds and the school's promotion of an inclusive national identity. However, as a result of England's ambivalent approach to Europe, as well as a curricular emphasis on national and multicultural values, the British and Turkish middle-class students I interviewed developed ethno-national identities. In contrast, as a result of their mainly workingclass backgrounds, youth at Millroad School and Tannberg Hauptschule privileged their national identities and did not consider Europe part of their hybrid identities.

Table 3 summarises, from a comparative research point of view, what we have learnt about young people's European knowledge, interests and identities.

There are very few other comparative studies of young people's political identities [4]. Notable are those of Convery et al. (1997) and Gordon et al. (2000). For example, Convery et al. adopted a post-positivist stance to argue that a much greater proportion of native youth felt 'totally European' (47.9 per cent) compared with Afro-Caribbeans (five per cent) and Asians (10.1 per cent) while 40 and 43.4 per cent of Afro-Caribbeans and Asians, respectively, felt 'partly European' compared with 31.8 per cent of native students. Arguably, the model of comparative research into students' identities was developed by a series of five Eurobarometer surveys (The Young Europeans) (European Commission 1982, 1989, 1991, 1997, 2001a). Questions on national and European identities have also been included in the Standard Eurobarometer since 1992 (European Commission 1992-). For example, in 2002, 38 per cent of Europeans regarded themselves as '(nationality) only', 48 per cent as '(nationality) and European', seven per cent as 'European and (nationality)' and 4 per cent as Europeans only. Since 1992, there have always been more people 
Table 3 Factors affecting young people's European knowledge and identities.

\begin{tabular}{|c|c|c|c|c|}
\hline & \multicolumn{2}{|c|}{ Germany } & \multicolumn{2}{|c|}{ England } \\
\hline & $\begin{array}{c}\text { Tannberg } \\
\text { Hauptschule }\end{array}$ & $\begin{array}{c}\text { Goethe } \\
\text { Gymnasium }\end{array}$ & $\begin{array}{l}\text { Millroad } \\
\text { School }\end{array}$ & $\begin{array}{l}\text { Darwin } \\
\text { School }\end{array}$ \\
\hline $\begin{array}{l}\text { Macro-political } \\
\text { level }\end{array}$ & \multicolumn{2}{|c|}{ Very strong European dimension } & \multicolumn{2}{|c|}{ Weak European dimension } \\
\hline Institutional level & $\begin{array}{l}\text { Working-class } \\
\text { inner-city }\end{array}$ & $\begin{array}{l}\text { Middle-class } \\
\text { inner-city }\end{array}$ & $\begin{array}{l}\text { Working-class } \\
\text { inner-city }\end{array}$ & $\begin{array}{l}\text { Middle-class } \\
\text { inner-city }\end{array}$ \\
\hline $\begin{array}{l}\text { (b) European } \\
\text { topics }\end{array}$ & Many & Many & Few & Few \\
\hline (c)School & Eurocentric & Multicultural & Celebrating & Multicultural \\
\hline approaches & education & Europeanness & diversity & Britishness \\
\hline $\begin{array}{l}\text { (d)European } \\
\text { knowledge }\end{array}$ & Higher & Higher & Lower & Lower \\
\hline $\begin{array}{l}\text { (e)European } \\
\text { identities }\end{array}$ & $\begin{array}{l}\text { Weak } \\
\text { ethno- } \\
\text { national }\end{array}$ & $\begin{array}{l}\text { Partial } \\
\text { national- } \\
\text { European }\end{array}$ & $\begin{array}{l}\text { Weak } \\
\text { national }\end{array}$ & $\begin{array}{l}\text { Weak } \\
\text { ethno- } \\
\text { national }\end{array}$ \\
\hline
\end{tabular}

who feel to some extent European than people who solely identify with their own nationality. However, the sense of sharing a common identity has not become more widespread over the years suggesting that the gap between European political elites and the public regarding European citizenship and identity is not closing. Although these mainly quantitative studies give us a broad insight into youth identities, little if any account has been provided of young people's voices to these issues. In contrast, this article has not only considered the complexity of factors affecting young people's European political knowledge, interests and identities, but has also discussed the ethnic and political dimensions of young people's hybrid identities.

\section{Concluding Remarks}

The different prioritisation of European agendas in Germany and England was clearly an important factor in explaining the differences between the political knowledge and identities of youth; whereas the school dynamics (ethos and curriculum approaches) were amongst the most important factors affecting young people's responses within one country. The article therefore raises important questions about the appropriateness of both the National Curriculum guidelines in England and the school curricula of subjects such as citizenship, geography and history, where European topics are currently only marginally included. Unlike in Germany where each type of secondary school has a mandatory curriculum for all ages and levels with very limited student choice below Year 11 (ages 16-17), the English system promotes subject specialisation at an early age and allows for young people to drop history, geography and foreign languages (i.e. subjects that are particularly suitable for promoting 'Europe') at Key Stage 4 (ages 14-16). The findings of this study not only suggest that it might help the new generation of European youth 
forge a loyalty to Europe if schools transformed nation-centred curricula into more inclusive learning approaches, but also highlighted the educational discrepancies within the EU. In order to avoid such gaps, it might be worth considering the potential of European educational standards (i.e. a European core curriculum with specified standards that all students must attain within a certain period) without falling into the normative trap of asserting that Europe is the only way forward.

Another example that highlights the gaps between European countries is the role of foreign language learning. There have been different responses to the European Commission's recommendation that all pupils should master at least two European languages in addition to their own by the end of their compulsory education (European Commission 2001b). In Germany, for instance, several federal states introduced legislation by which compulsory foreign language learning starts in the first year of primary school and sixth-form students are obliged to take one European language other than German as one of their A-level subjects. In England, by contrast, language learning beyond the age of 14 ceased to be compulsory in September 2005 and the government suggested that 'whilst not making it a compulsory part of the National Curriculum, we will give each child an entitlement to learn a language at primary level by 2010' (Department for Education and Skills 2002 , p. 4). Arguably, only three years of compulsory foreign language learning is 'a retrograde step' (e.g. Nuffield Foundation 2002) that could disadvantage British youth in terms of European job opportunities and EU funding to study abroad.

The evidence in this article also suggests that in countries with strong European agendas (e.g. Germany) and where Europe is conceptualised as an inclusive multiethnic concept, young people from diverse ethno-religious backgrounds relate positively to Europe. In contexts of strong European agendas and where Europe is constructed in ethnocentric/Eurocentric terms, minority ethnic youth like the Turkish Muslims seemed to privilege ethno-national identities. In contrast, the findings suggest that in countries with weak European agendas (e.g. England) and where Europe is marginalised in school curricula, young people struggle to relate to Europe. While some countries see Europe as a common bond that may hold the different racial and ethno-religious communities together at a time of increasing globalisation, others (like England) promote national agendas for example through citizenship education. Regardless of whether one wants to promote an inclusive concept of Europe or the nation-state or both, the underlying question is also how to integrate minority ethnic youth into host societies and how to respond to their particular educational needs. If we want to increase young people's European political knowledge, interests and identities, then we need to promote both diversity and solidarity. And if we want to connect young people with the EU project, then we should address their 'information gaps' (Chisholm 1997) by promoting initiatives such as Ploteus (provides information on learning opportunities and exchanges), the European Youth Portal (www.europa.eu/youth) and the Youth Foundation. 


\section{Acknowledgements}

I would like to thank the British Economic and Social Research Council (ESRC), the Cambridge European Trust and Clare Hall College Cambridge for sponsoring the research upon which this article is based; and the Hellenic Foundation for European and Foreign Policy (ELIAMEP) for inviting me to present some of my findings to European experts.

\section{Notes}

[1] An earlier version of this paper was presented to the Halki International Seminars in Spetses, Greece, June 2006.

[2] The Green paper on the European dimension in education suggested ways of cooperation among students, parents, teachers and administrators, and thus sought for enactment of Article 126 of the Maastricht Treaty (Council of Ministers of Education 1993).

[3] For some theorists (e.g. Yuval-Davis 1997; Modood 2000) the notion of hybridity or hybridisation remains insufficient in providing an alternative to essentialist conceptualisations of identity. However, rather than focusing on notions of hybridity per se, this article acknowledges that identities shift and change and are affected by the social context (e.g. macro-political, schools) young people live in.

[4] Other comparative European youth studies focus more on young people's attitude towards Europe and the EU, such as Chisholm et al. (1995), Angvik and von Borries (1997) and von Borries (1999).

\section{References}

Angvik, M. \& von Borries, B. (eds) (1997) Youth and History: A Comparative European Survey on Historical Consciousness and Political Attitudes among Adolescents, Körber-Stiftung, Hamburg.

Auernheimer, G. (1990) 'How black are the German Turks? Ethnicity, marginality and interethnic relations for young people of Turkish origin in Germany', in Childhood, Youth, and Social Change: A Comparative Perspective, eds L. Chisholm, P. Büchner, H. Krüger \& P. Brown, The Falmer Press, Basingstoke.

Bhabha, H. K. (1990) Nation and Narration, Routledge, London.

Brah, A. (1996) Cartographies of Diaspora: Contesting Identities, Routledge, London.

Butler, J. (1997) The Psychic Life of Power: Theories in Subjection, Stanford University Press, Stanford.

Caglar, A. S. (1997) 'Hyphenated identities and the limits of "culture", in The Politics of Multiculturalism in the New Europe: Racism, Identity and Community, eds T. Modood \& P. Werbner, Zed Books, London.

Chisholm, L. (1997) Building citizenship with a European dimension: where are we now? A preliminary analysis of Young Europeans 1997 data, Unpublished Manuscript, European Commission, Brussels.

Chisholm, L., Du Bois-Reymond, M. \& Coffield, F. (1995) 'What does Europe mean to me? Dimensions of distance and disillusion amongst European students', in European Yearbook on Youth Policy and Research: The Puzzle of Integration, ed. Circle for Youth Research Cooperation in Europe, de Gruyter, Berlin.

Convery, A., Evans, M., Green, S., Macaro, E. \& Mellor, J. (1997) Pupils' Perceptions of Europe: Identity and Education, Cassell, London.

Convey, A. \& Merritt, A. (2000) 'The United Kingdom', in Education in a Single Europe, eds C. Brock \& W. Tulasiewicz, Routledge, London. 
Council of Ministers of Education (1988) 'Resolution of the Council and the Ministers of Education: meeting within the Council on the European dimension in education of 24 May 1988, 88/C/177/02', Official Journal of the European Communities, vol. C 177, pp. 5-7.

Council of Ministers of Education (1993) Green Paper on the European Dimension of Education, Office for Official Publications of the European Communities, Luxembourg.

Council of the European Union (1997) 'Treaty of Amsterdam', Official Journal of the European Communities, vol. C 340, 10 November, pp. 145-172.

Council of the European Union (2004) Treaty Establishing a Constitution for Europe, [Online] Available at: http://europa.eu/constitution/index_en.htm (accessed 11 October 2006).

Department for Education and Skills (2002) Green Paper 14-19: Extending Opportunities, Raising Standards, [Online] Available at: http://www.dfes.gov.uk/14-19greenpaper/download/ DfESLanguageLearning.pdf (accessed 17 October 2003).

Department of Education and Science (1991) EC, UK and Council of Europe Resolutions in Relation to the European Dimension in Education, [Online] Available at: http://www. neelb.org.uk/cass/languages/euro-pean/zl00017l.htm\#resolutions (accessed 16 April 2003).

Derrida, J. (1981) Positions, trans. A. Bass, Athlone, London.

Dolby, N.E. (2001) Constructing Race: Youth, Identity and Popular Culture in South Africa, State University of New York Press, Albany, NY.

Enneli, P., Modood, T. \& Bradley, H. (2005) Young Turks and Kurds: A Set of 'Invisible' Disadvantaged Groups, Joseph Rowntree Foundation, York.

European Commission (1982) The Young Europeans, Brussels, European Commission.

European Commission (1989) The Young Europeans, Brussels, European Commission.

European Commission (1991) The Young Europeans, European Commission, Brussels.

European Commission (1992-) Standard Eurobarometer, [Online] Available at: http://europa.eu. int/comm/public_opinion/archives/eb_arch_en.htm (accessed 11 October 2006).

European Commission (1997) The Young Europeans, European Commission, Brussels.

European Commission (2001a) The Young Europeans, European Commission, Brussels.

European Commission (2001b) Special Eurobarometer Europeans and Languages, [Online] Available at: http://europa.eu.int/comm/public_opinion/archives/eb/ebs_147_summ_en. pdf (accessed 22 November 2002).

Faas, D. (2007) 'Turkish youth in the European knowledge economy: an exploration of their responses to Europe and the role of social class and school dynamics for their identities', European Societies, vol. 9, no. 4, pp. 573-599.

Foucault, M. (1980) 'Truth and power; the subject of power; and two lectures', in Power/Knowledge: Selected Interviews and Other Writings 1972-77, ed. C. Gordon, Harvester, Brighton.

Foucault, M. (1988) 'Technologies of the self', in Technologies of the Self: A Seminar with Michel Foucault, eds L. Martin, H. Gutman \& P. Hutton, Tavistock, London.

Gordon, T., Holland, J. \& Lahelma, E. (2000) Making Spaces: Citizenship and Difference in Schools, Macmillan, Basingstoke.

Hall, S. (1992) 'New ethnicities', in 'Race', Culture and Difference, eds J. Donald \& A. Rattansi, Sage Publications, London.

Hall, S. (1996) 'Who needs identity', in Questions of Cultural Identity, eds S. Hall \& P. du Gay, Sage Publications, London.

Küçükcan, T. (1999) Politics of Ethnicity, Identity and Religion: Turkish Muslims in Britain, Ashgate, Aldershot.

Kultusministerkonferenz (1990) Europa im Unterricht: Beschluss der Kultusministerkonferenz vom 08.06.1978 in der Fassung vom 07.12.1990, [Online] Available at: http:// 
bebis.cidsnet.de/faecher/feld/europa/unterricht_dateien/kmkeuropa.htm (accessed 26 March 2003).

Kultusministerkonferenz (1992) Zur europäischen Dimension im Bildungswesen: Beschluss der Kultusministerkonferenz vom Juni 1992, Sekretariat der Ständigen Konferenz der Kultusminister der Länder in der Bundesrepublik Deutschland, Bonn.

Mac an Ghaill, M. (1999) Contemporary Racisms and Ethnicities: Social and Cultural Transformations, Open University Press, Buckingham.

MacLure, M. (2003) Discourse in Educational and Social Research, Open University Press, Maidenhead.

Mercer, K. (2000) 'A sociography of diaspora', in Without Guarantees: In Honour of Stuart Hall, eds P. Gilroy, L. Grossberg \& A. McRobbie, Verso, London.

Modood, T. (2000) 'Anti-essentialism, multiculturalism and the "recognition of religious groups"', in Citizenship in Diverse Schools, eds W. Kymlicka \& W. Norman, Oxford University Press, Oxford.

Nuffield Foundation (2002) Nuffield Languages Team responds to the 14 to 19 Green Paper, [Online] Available at: http://languages.nuffieldfoundation.org/languages/news/nw 0000000246.asp (accessed 9 October 2002).

Risse, T. \& Engelmann-Martin, D. (2002) 'Identity politics and European integration: the case of Germany', in The Idea of Europe: from Antiquity to the European Union, ed. A. Pagden, Cambridge University Press, Cambridge.

Sen, F. \& Goldberg, A. (1994) Türken in Deutschland: Leben zwischen zwei Kulturen, Verlag C.H. Beck, München.

Skeggs, B. (1997) Formations of Class and Gender: Becoming Respectable, Sage, London.

Soysal, Y., Bertilotti, T. \& Mannitz, S. (2005) 'Projections of identity in French and German history and civics textbooks', in The Nation, Europe and the World, eds H. Schissler \& Y. Soysal, Berghahn Books, Oxford.

Tizard, B. \& Phoenix, A. (2002) Black, White or Mixed Race? Race and Racism in the Lives of Young People of Mixed Parentage, Routledge, London.

Tulasiewicz, W. (1993) 'The European dimension and the national curriculum', in The Multicultural Dimension of the National Curriculum, eds A. S. King \& M. J. Reiss, Falmer, London.

von Borries, B. (1999) 'A cross-cultural comparison of students' concepts of Europe', in European Yearbook on Youth Policy and Research: Intercultural Reconstruction, ed. Circle for Youth Research Cooperation in Europe, de Gruyter, Berlin.

Yuval-Davis, N. (1997) 'Ethnicity, gender relations and multiculturalism', in Debating Cultural Hybridity: Multicultural Identities and the Politics of Antiracism, eds P. Werbner \& T. Modood, Zed Books, London. 